\title{
Amyloidosis presenting as multiple vertebral fractures
}

\author{
Ricardo Vieira Botelho', Matheus Fernandes de Oliveira ${ }^{2}$, José Marcus Rotta ${ }^{1}$ \\ Hospital do Servidor Público Estadual de São Paulo, Instituto de Assistência Médica ao Servidor Público Estadual \\ (lamspe), São Paulo, Brazil.
}

\section{ABSTRACT}

Amyloidosis is a plasma cell disorder characterized by the overproduction and tissue deposition of a monoclonal IG light chain or fragments. Musculoskeletal and soft tissue manifestations are arthropathy, myopathy, bone lesions, and lymphadenopathy. It can also present with symptoms and signs that mimic a variety of rheumatic conditions, such as scleroderma, rheumatoid arthritis, Sjögren's syndrome polymyalgia rheumatica, a myeloma or a bone tumour. We describe the case of a 64-year-old white woman with an acute history of fall from own height in whose investigation revealed fractures in T8, T9, T11 and L1. In order to determine the nature of lesion, the patient was submitted to percutaneous biopsy guided by fluoroscopy of T11, without any surgical complications. Pathological findings were compatible with deposition of amyloid protein and amyloidosis. Amyloidosis must be considered in differential diagnosis of pathological fractures together with other osteopenic and lytic conditions, such as bone metastasis, metabolic and infectious diseases.

\section{KEYWORDS}

Low pain, spinal diseases, amyloidosis.

\section{RESUMO}

Apresentação de amiloidose com múltiplas fraturas vertebrais

A amiloidose é uma doença caracterizada por produção excessiva e depósito tecidual de cadeias leves de imunoglobulina monoclonal. Manifestações musculoesqueléticas incluem artropatia, miopatia, lesão óssea e linfadenomegalia. Descrevemos um caso de uma paciente de 64 anos com história recente de queda de própria altura com estudo de imagem revelando fratura de T8, T9, T11 e L1. A paciente foi submetida à cifoplastia de $L 1$ para tratamento da dor associada à fratura, e a biópsia óssea realizada durante o procedimento revelou tratar-se de amiloidose. Esse diagnóstico também deve ser considerado no diagnóstico diferencial de fraturas patológicas em qualquer idade.

\section{PALAVRAS-CHAVE}

Dor lombar, doenças da coluna vertebral, amiloidose.

1 Neurosurgeon, Department of Neurosurgery, Hospital do Servidor Público Estadual de São Paulo, Instituto de Assistência Médica ao Servidor Público Estadual (Iamspe), São Paulo, SP, Brazil.

2 Neurosurgery Residency Program, Department of Neurosurgery, Hospital do Servidor Público Estadual de São Paulo, São Paulo, SP, Brazil. 


\section{Introduction}

Primary or AL amyloidosis is a plasma cell disorder characterized by the overproduction and tissue deposition of a monoclonal IG light chain or fragments containing the light-chain variable region (VL).$^{1-3}$ Light chain deposition produces tissue damage and eventually organ failure, leading to death in untreated patients. Male predominance has been reported for various amyloid musculoskeletal and soft tissue manifestations, such as arthropathy, myopathy, bone lesions, and lymphadenopathy.,3

AL amyloidosis can also present with symptoms and signs that mimic a variety of rheumatic conditions, such as scleroderma, rheumatoid arthritis, Sjögren's syndrome polymyalgia rheumatica, a myeloma or a bone tumour. ${ }^{1-5}$

We describe an unusual case of pathological vertebral fractures secondary to amyloidosis.

\section{Case description}

A 64-year-old white woman with an acute history of fall from own height one month ago, developing pro- gressive low back pain not alleviated by usual analgesics. She searched for medical help referring amelioration of symptoms in supine position and worsening while standing.

Her previous medical files revealed blood hypertension, routinely followed by clinician and controlled with diuretics and beta blockers. She denied fever of weight loss or any other symptom. Her physical examination, including neurological status, was normal. She was submitted to radiological evaluation. Spine plain radiographs immediately revealed fractures in T8, T9, T11 and L1. Spinal tomography confirmed the findings and showed traumatic spondylolisthesis of T12-L1. A magnetic resonance revealed fractures with loss of approximately $90 \%$ of body height in T9 and L1, 50\% in T8 and 30\% in T9. In T8 and T11, the fractures were mainly axial loading compressive fractures, while in T9 and L1 there was explosion of vertebral body, invading vertebral canal (Figure 1). Facing diagnosis of pathological traumatic spine fractures in a white woman, some aetiologies were thought. Among possible diagnosis, osteoporosis, Paget disease and tumoral aetiology were considered such as linfoproliferative neoplasms and metastatic lesions. Rheumatologic evaluation displayed Z-score in bone densitometry of $-4,6$, diagnosing osteoporosis. Laboratorial findings were unremarkable, except for an

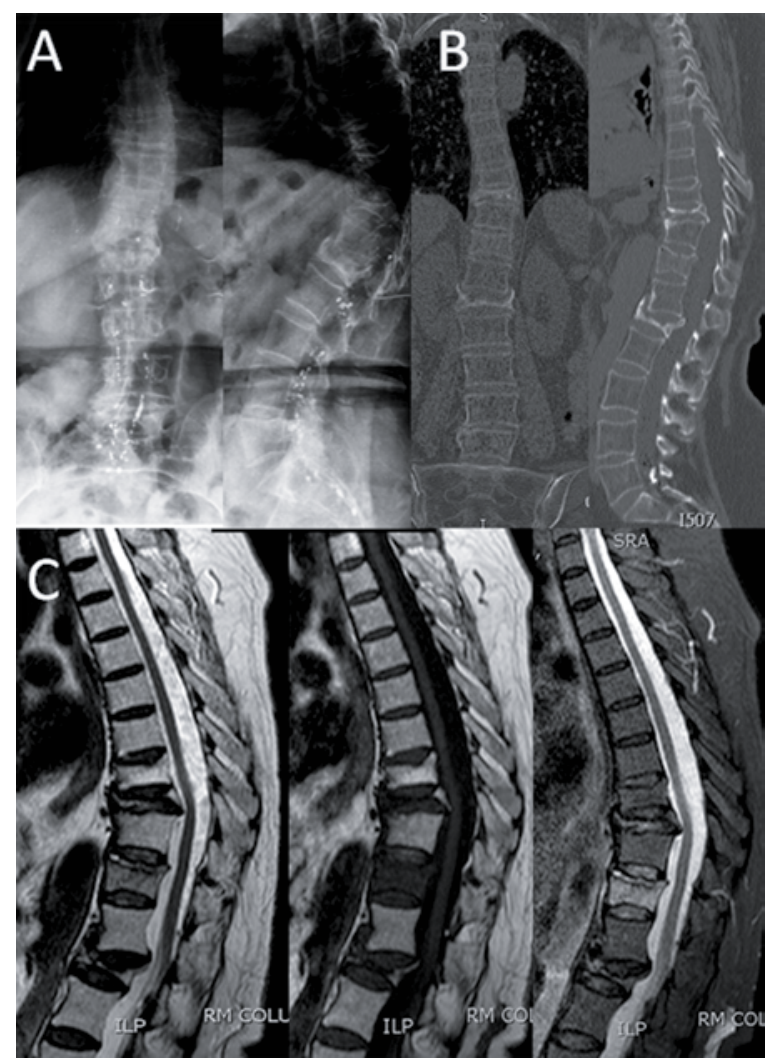

Figure 1 - Radiological evaluation. (A) Spine plain radiographs revealing fractures in T8, T9, T11 and L1. (B) Spinal tomography confirmed the findings and showed traumatic spondylolisthesis of T12-L1. (C) Sagittal magnetic resonance imaging displaying the fractures. 
elevated beta 2 microglobulin of 2,376 (normal value $=$ 2,144 ). In order to determine the nature of lesion, the patient was submitted to percutaneous biopsy guided by fluoroscopy of T11, without any surgical complications.
Pathological findings were compatible with deposition of amyloid protein and amyloidosis (Figure 2). She was forwarded to Rheumatology Service for further approach.
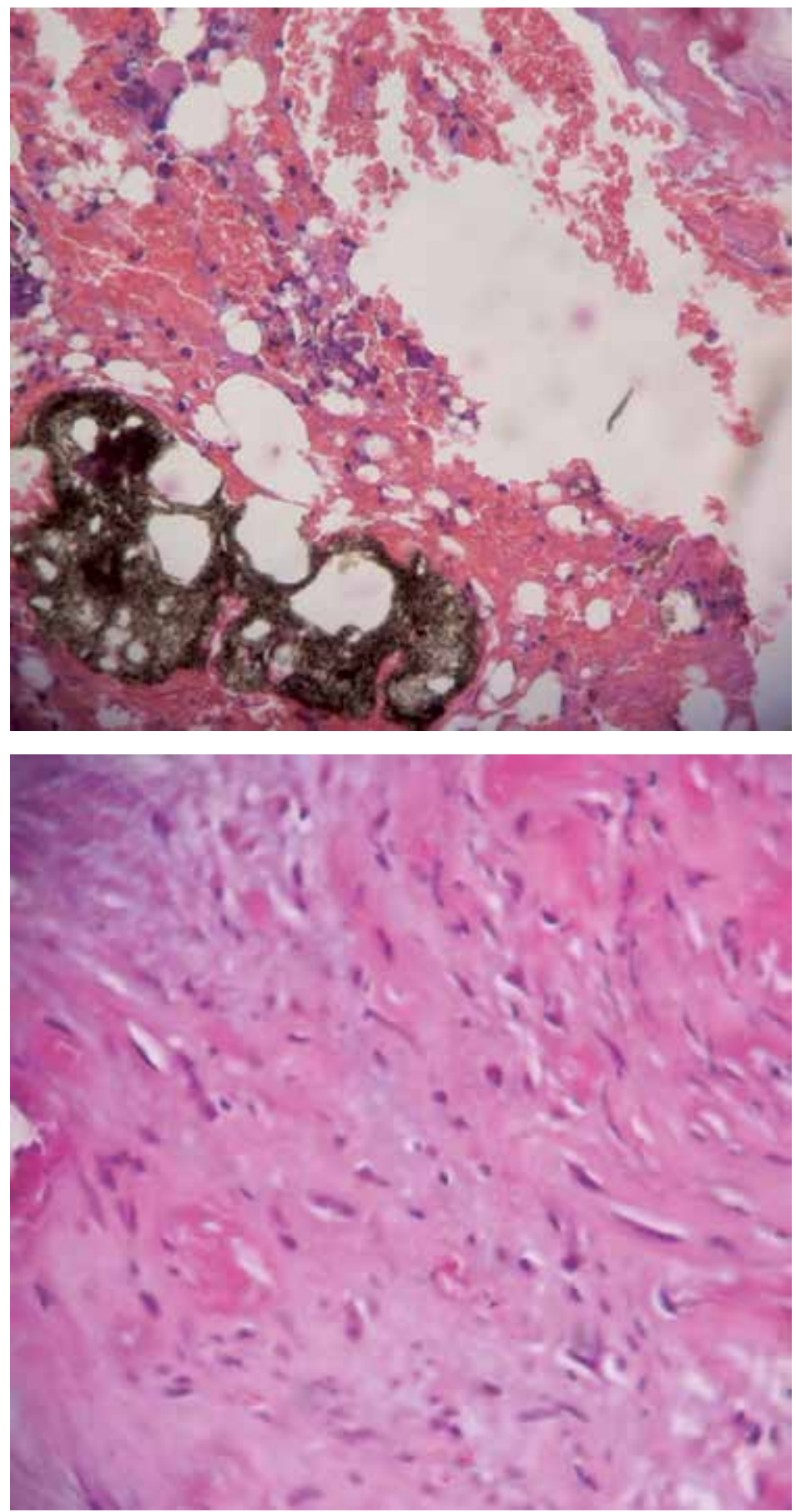

Figure 2 - Pathological findings. In hematoxilin-eosin stain, amyloid deposits presenting as eosinophilic masses among bone tissue. 


\section{Discussion}

Approximately $40 \%$ of patients with AL amyloidosis have evidence of soft tissue and bone involvement and this tend to occur in the setting of multiple organ involvement..$^{1-3}$ Amyloid infiltration into vertebrae leading to spondylolisthesis or fracture are rare manifestations. Primary solitary amyloidoma of the spine is also very rare, with few anedoctal cases reported. It has an unusually aggressive appearance characterized by local deposition of amyloid with bony destruction and soft-tissue extension. ${ }^{4,5}$ The thoracic spine is most commonly involved, followed by the cervical spine. Bony destruction caused by spinal amyloidoma mimics other aggressive pathologic processes, including infection, neoplasm, or malignancy and metabolic diseases. ${ }^{4,5}$

The MR imaging signal-intensity characteristics are similar to those of primary amyloid lesions elsewhere in the bones and soft tissues and include low-to-intermediate signal intensity on T1WI, intermediate-to-low signal intensity on $\mathrm{T} 2 \mathrm{WI}$, and variable enhancement on contrast-enhanced T1WI. ${ }^{3}$

Amyloidosis must be considered in differential diagnosis of pathological fractures together with other osteopenic and lytic conditions, such as bone metastasis, metabolic and infectious diseases.

\section{Conflicts of interest}

The authors declare no conflicts of interest.

\section{References}

1. Prokaeva T, Spencer B, Kaut M, Ozonoff A, Doros G, Connors $\mathrm{LH}$, et al. Soft tissue, joint, and bone manifestations of AL amyloidosis: clinical presentation, molecular features, and survival. Arthritis Rheum. 2007;56(11):3858-68.

2. M'bappé P, Grateau G. Osteo-articular manifestations of amyloidosis. Best Pract Res Clin Rheumatol. 2012;26(4):459-75.

3. Parmar H, Rath T, Castillo M, Gandhi D. Imaging of focal amyloid depositions in the head, neck, and spine: amyloidoma. AJNR Am J Neuroradiol. 2010;31(7):1165-70.

4. Haridas A, Basu S, King A, Pollock J. Primary isolated amyloidoma of the lumbar spine causing neurological compromise: case report and literature review. Neurosurgery. 2005;57(1):E196.

5. Iplikcioglu AC, Bek S, Gokduman CA, Cosar M, Sav A. Primary solitary cervical amyloidosis: case report and review of the literature. Spine (Phila Pa 1976). 2007;32(1):E45-7.

Correspondence address

Matheus Fernandes de Oliveira

Av. Luís Góis, 1333, ap. 23, Vila Mariana

04043-150 - São Paulo, SP, Brazil

Telephone: (55 11) 5088-8996; Telefax: (55 11) 5088-8379

E-mail: mafernoliv@yahoo.com.br 